\section{Uptake Efficiency of Phosphorus in Different Light Environments by Zinnia (Zinnia elegans) and Vinca (Catharanthus roseus)}

\author{
Jonathan M. Frantz ${ }^{1,2}$ \\ USDA-ARS, $2801 \mathrm{~W}$. Bancroft, MS 604, Toledo, OH 43606
}

Additional index words. nutrient use efficiency, water use efficiency, shade, greenhouse crop production, floriculture

\begin{abstract}
Two warm-season bedding plant species, zinnia (Zinnia elegans) and vinca (Catharanthus roseus), were used to determine if phosphorus $(P)$ supply should be adjusted with light supply, and if deficiency and/or oversupply symptoms were apparent at different $P$ rates when growth rates were altered by light levels. An additional goal was to determine the influence of $P$ and light on overall $P$ uptake efficiencies and water use efficiencies. Plants were grown in a greenhouse with or without shade over portions of the bench and supplied $0.1,0.2,0.5,1,2$, or $4 \mathrm{~mm} P$ along with complete nutrient solution as needed with no leaching fraction. Optimum plant growth and flower development rate occurred at a $P$ supply of $0.5 \mathrm{~mm}$ regardless of the light supply. Plant growth was greatly reduced by $P$ supply below $0.5 \mathrm{~mm}$ regardless of shade conditions. Tissue $P$ concentration was not influenced by light, but overall $P$ content ( $\mathrm{mg} P$ per plant) was higher when plants were grown without shading as a result of larger plants in higher light environments. The appearance or severity of deficiency symptoms also was not influenced by light. Water use efficiency was maximized when growth was not limited by $P$ supply (at or above $0.5 \mathrm{~mm}$ ). One hundred percent recovery of applied $P$ was obtained at the $0.5 \mathrm{~mm} P$ supply in vinca, whereas recovery was less at the same $P$ supply in zinnia. These results indicate no benefit for plant growth and flowering to $P$ supply above $0.5 \mathrm{~mm}$ and illustrate how $P$ content is demand-driven. However, there was no induction or delay of nutrient stress symptoms as a result of different plant growth rates in the different light differences environments.
\end{abstract}

Use of shade curtains or whitewash are common strategies to reduce plant and air temperature in greenhouses (Aldrich and Bartok, 1994). These approaches typically reduce temperatures by 1 to $4{ }^{\circ} \mathrm{C}$, depending on the conditions, but photosynthetic light is also reduced by $30 \%$ to $75 \%$ (Aberkani et al., 2010; Al-Arifi, 2006). The reduced radiation results in lower photosynthesis (Taiz and Zeiger, 1991), water use (Nobel, 1991), nutrient demand (Adams, 1980; Chapin et al., 1995), fewer or smaller flowers (Oh et al., 2009), and increases in height along with thinner leaves (Pramuk and Runkle, 2005; Stanton et al., 2010).

The influence of light on growth, flowering, and crop quality is well known and documented. Photosynthetically, a reduction of a certain percentage of light is often accompanied by an approximately equal reduction in whole plant photosynthesis (Frantz and Bugbee, 2005; Nemali and van Iersel, 2004).

Received for publication 8 Nov. 2012. Accepted for publication 19 Mar. 2013.

I thank Alycia Pittenger, Russell Friedrich, and Doug Sturtz for their assistance throughout the work.

${ }^{1}$ Current address: DuPont Pioneer, 7305 NW 62 ${ }^{\text {nd }}$ Avenue, P.O. Box 287, Johnston, IA 50131.

${ }^{2}$ To whom reprint requests should be addressed; e-mail jonathanfrantz319@gmail.com.
Shading [or a reduction in daily light integral (DLI)] also leads to decreases in flowering rate (Blanchard et al., 2011a, 2011b) and potentially alters plant or fruit quality, although the timeframe of those delays relative to shade application can vary depending on the crop (Gent, 2007).

Reduction of incoming radiation and corresponding cooler conditions reduces water use in plants as well. In fact, Kim et al. (2011) found that DLI was the most significant correlation with water use. Additionally, Garland et al. (2012) found that DLI was strongly correlated to water use in plants, attributable in large part to larger plants and more leaf area in treatments receiving greater DLI. However, water use efficiency (WUE; amount of growth per unit of water; $\mathrm{mg} \cdot \mathrm{L}^{-1}$ ) tended to decline in higher DLIs.

In floricultural crops, $\mathrm{P}$ supply can influence flowering and plant height. Whitcher et al. (2005) observed increases in plant height and flower number with both new guinea impatiens (Impatiens hawkeri) and vinca as $\mathrm{P}$ supply and foliar concentrations increased. Optimum rates, based on flower number, were 1 and $1.25 \mathrm{~mm} P$ for new guinea impatiens and vinca, respectively. The enhancement of flowering with $\mathrm{P}$ has resulted in a number of commercial products; so-called "bloom enhancer" fertilizers are sold and marketed with the promise of greater flowering as a result of much higher $\mathrm{P}$ concentrations and a nitrogen:P ratio of 1:2.5 to 1:5 (e.g., Bloom Booster, Scotts Miracle-Gro Co., Marysville, $\mathrm{OH}$; Jack's Classic Blossom Booster, JR Peters Inc., Allentown, PA; Dr. Earth Bud and Bloom Booster, Dr. Earth Co., Winters, CA). The belief in the product claims and aggressive marketing campaigns ensures their widespread use in commercial facilities.

In a comprehensive series of experiments, the effects of $\mathrm{P}$ on height were evaluated for tomato (Solanum lycopersicum), marigold (Tagetes erecta), petunia $($ Petunia $\times$ hybrida), impatiens (Impatiens walleriana), and gomphrena (Gomphrena globosa) (Nelson et al., 2002, 2012). For these crops, height generally increased with tissue $P$ concentration up to $10 \mathrm{~g} \cdot \mathrm{kg}^{-1}$ ( $1 \%$ dry weight $)$ and occasionally continued to increase with high $\mathrm{P}$ concentrations. With few exceptions, $P$ sufficiency for bedding plants is reported to be well below $10 \mathrm{~g} \cdot \mathrm{kg}^{-1}$ and is often as low as $2.5 \mathrm{~g} \cdot \mathrm{kg}^{-1}$ (Gibson et al., 2007; Mills and Jones, 1996). This indicates that although the plant does not require greater amounts of $\mathrm{P}$, supraoptimal levels of $\mathrm{P}$ can cause responses that are undesirable in a production environment. So although flower number may be enhanced with extra $\mathrm{P}$, height can be simultaneously increased leading to additional use of plant growth regulators to decrease stretch.

Recommendations for P supply to plants are based on appearance of deficiency symptoms (Gibson et al., 2007), delays in growth and development, or generalized surveys of healthy plants in commercial production systems (Mills and Jones, 1996). Research-grade greenhouse conditions are typically used (e.g., Jeong et al., 2009), which may or may not be accurate representations of commercial production conditions. That is, in practice, growers will need to use shade curtain management for temperature control and therefore expose their plants to less-than-optimal light environments. Under those conditions, will the recommendations for nutrient supply hold true or will nutrient supply need to be altered to match nutrient demand by the plant? If the supply is altered, will plant height and flowering response be influenced under less-than-ideal growth conditions? In cases in which fertigation (the combination of fertilization and irrigation through the use of water-soluble fertilizer) is used, will water and nutrient use efficiency be impacted as DLI is altered as a result of shading to help cool a greenhouse?

Growing two warm-season floriculture crops in a greenhouse with and without shading, varying concentrations of $\mathrm{P}$ were used to test general nutrient recommendations in commercially realistic conditions. The goals of the research were to determine: 1) if P supply should be adjusted or lowered as light decreases; 2) if deficiency and/or oversupply symptoms would be apparent at different $P$ rates when growth rates decreased as a result of different light levels; and 3) the influence of $\mathrm{P}$ and light on overall $\mathrm{P}$ uptake efficiency and WUE. As a result of this research, appropriate rates of $\mathrm{P}$ supply could be 
identified and estimates of under- or oversupply could be made.

\section{Materials and Methods}

Seeds of vinca 'Cooler Grape' were sown 7 July 2009 in seedling trays (Series 5005; Smithers-Oasis, Kent, OH), hydrated with tap water, and placed in a dark growth chamber set to a constant $22{ }^{\circ} \mathrm{C}$ until germination. After germination, the growth chamber was controlled to $25 / 21{ }^{\circ} \mathrm{C}$ day/night with a 16 -h photoperiod. Seedlings were under a DLI of $8.6 \mathrm{~mol} \cdot \mathrm{m}^{-2} \cdot \mathrm{d}^{-1}$ during this stage. Seeds of zinnia 'Oklahoma White' were sown in a similar manner 2 weeks later but received light from sowing until transplant.

Two weeks after sowing zinnia and 4 weeks after sowing vinca, seedlings were transplanted into $10-\mathrm{cm}$ plastic containers filled with soilless media composed of $70 \%$ peat and $30 \%$ perlite. At mixing, substrate was amended with $3 \mathrm{~g} \cdot \mathrm{L}^{-1}$ dolomitic lime and 0.59 g. $\mathrm{L}^{-1}$ micronutrient charge (Micromax; Scott's Co., Marysville, OH; with $12 \%$ iron, $2.5 \%$ manganese, $1.0 \%$ zinc, $0.5 \%$ zinc, $0.1 \%$ boron, and $0.05 \%$ molybdenum by weight). Planted seedlings were placed in a glassroofed, pad-and-fan-cooled greenhouse set to $28^{\circ} \mathrm{C}$ day and $23{ }^{\circ} \mathrm{C}$ night. Humidity ranged from $60 \%$ to $85 \%$ daily average relative humidity for the duration of the study ( 9 weeks for zinnia and 6 weeks for vinca). Each pot was placed into a saucer to prevent leachate loss during irrigations. Electrical conductivity of the substrate was not measured.

The greenhouse was divided into three complete blocks. Each block consisted of a bench with one randomly allocated end containing a frame with a single layer of window screen (40 squares $/ \mathrm{cm}^{2}$ ) that reduced the photosynthetically active radiation $(P A R)$ by $47 \%$ and the other end of the same bench left unshaded. In the shaded and unshaded sections of each block, a quantum sensor (Model QSO-S; Apogee Instruments, Logan, UT) was connected to a data logger (CR10X; Campbell's Scientific, Logan, UT) and recorded tosynthetic photon flux and used to calculate DLI in $\mathrm{mol} \cdot \mathrm{m}^{-2} \cdot \mathrm{d}^{-1}$.

Plants were fertigated (irrigation with fertilizer combined) after transplanting with one of six nutrient solutions containing complete nutrients but variable amounts of P. Phosphorus treatments were (in $\mathrm{mm}$ ) 0.1, 0.2, 0.5, 1.0, 2.0, and 4.0 supplied as $\mathrm{KH}_{2} \mathrm{PO}_{4}$ (Table 1). $\mathrm{P}$ treatments received the same amounts of each of the previous 10-minute average pho-

potassium through the addition of $\mathrm{K}_{2} \mathrm{SO}_{4}$; sulfur supply varied concomitantly with $\mathrm{P}$ supply. Plants were checked once daily to determine watering needs; each container was judged, by picking it up, if water should be added that day. Up to $200 \mathrm{~mL}$ per fertigation was provided, slowly to each container between irrigations, but ranged from $30 \mathrm{~mL}$ to $200 \mathrm{~mL}$ when fertigation was required. There was occasionally a range of fertigation added within a given treatment group because some containers required more than others. Amounts added to each pot were recorded daily. Water use includes both transpired through the plant and that evaporated from the substrate surface. Date of flowering was also recorded for each plant on the initial appearance of color.

At harvest, three replicate plants from each treatment were analyzed for flower, branch, and bud number and final plant height was recorded. Stems were separated from the leaves, and the tissue was washed with $0.1 \mathrm{~N}$ $\mathrm{HCl}$, rinsed with 18 mega-ohm deionized water, and dried in a forced-air oven at $55{ }^{\circ} \mathrm{C}$ for $48 \mathrm{~h}$. Dry stem mass and leaf mass were recorded separately and then the tissue was ground with a mortar and pestle to pass a 100 mesh screen. Two 1-cm diameter cores of the substrate and root mass were taken from each pot and dried in the same forced-air oven for subsequent analysis.

Elemental analysis. A 0.15-g sample was digested in a microwave digester (MARS; CEM Corp., Matthews, NC) using a modified Environmental Protection Agency (EPA) method (EPA method 3051 with an additional peroxide step). Nutrient concentration for $\mathrm{P}$ was determined with inductively coupled plasma optical emission spectroscopy (Model IRIS Intrepid II; Thermo Corp., Waltham, MA). A quality control was run every 10 samples and if any element was determined to be more than $10 \%$ higher or lower than the standard value, the instrument was recalibrated. Tomato standards (NIST reference material 1573) were compared every 20 samples and tomato and spinach standards (NIST reference material 1570a) were compared every 40 samples.

The cored substrate-root samples were pooled from each pot and from this, $0.15 \mathrm{~g}$ was weighed and digested in a similar manner as the plant tissue. Digested solution was filtered with a $2-\mu \mathrm{m}$ filter (Watman's No. 1; Fisher Scientific, Pittsburgh, PA) and analyzed for total $P$. This included $P$ from substrate components (e.g., peat, perlite) and,

Table 1. Total phosphorus (P) supplied (mg) in greenhouse production of vinca and zinnia plants in 10-cm pots grown either in sun or under nearly $50 \%$ shade and fertilized with a complete nutrient solution with $\mathrm{P}$ concentrations varying from 0.1 to $4.0 \mathrm{~mm}$.

\begin{tabular}{llllrrrr}
\hline & \multicolumn{7}{c}{ P concn (mM) } \\
\cline { 3 - 7 } & & 0.1 & 0.2 & 0.5 & 1.0 & 2.0 & 4.0 \\
\hline Vinca & Sun & $5.3 \mathrm{i}^{\mathrm{z}}$ & $10.9 \mathrm{hi}$ & $29.7 \mathrm{fg}$ & $59.4 \mathrm{e}$ & $118.8 \mathrm{c}$ & $237.7 \mathrm{a}$ \\
& Shade & $4.1 \mathrm{i}$ & $8.16 \mathrm{i}$ & $20.2 \mathrm{gh}$ & $40.3 \mathrm{f}$ & $82.7 \mathrm{~d}$ & $161.2 \mathrm{~b}$ \\
\multirow{2}{*}{ Zinnia } & Sun & $4.6 \mathrm{~h}$ & $12.7 \mathrm{~h}$ & $50.3 \mathrm{fg}$ & $103.6 \mathrm{e}$ & $208.2 \mathrm{c}$ & $416.4 \mathrm{a}$ \\
& Shade & $3.6 \mathrm{~h}$ & $8.8 \mathrm{~h}$ & $35.2 \mathrm{~g}$ & $70.2 \mathrm{f}$ & $142.9 \mathrm{~d}$ & $284.2 \mathrm{~b}$ \\
\hline
\end{tabular}

${ }^{\mathrm{z}}$ All data are means $(\mathrm{n}=18)$; values not sharing a common letter within a species are significantly different (Tukey's honestly significant difference test; $\alpha=0.05$ ). depending on the treatment, could substantially add to the total $\mathrm{P}$ available to the plant over the course of the experiment.

Carbohydrate analysis. Dried tissue samples $(50 \mathrm{mg}$ ) were weighed and ground, and $2 \mathrm{~mL}$ phosphate buffer $(\mathrm{pH}=7.2)$ was added and thoroughly mixed. After centrifugation at $16,000 \times g$ for $10 \mathrm{~min}$ at $4{ }^{\circ} \mathrm{C}$, the supernatant was transferred into a clean tube. A 5\% phenol solution $(0.5 \mathrm{~mL}$ of $5 \%$ phenol $)$ was added to the supernatant followed by $2.5 \mathrm{~mL}$ concentrated sulfuric acid $(18 \mathrm{M})$. The mixture was allowed to sit for $10 \mathrm{~min}$. Absorbance at $470 \mathrm{~nm}$ was measured with a spectrophotometer and compared against a standard curve made with glucose prepared in the same manner. This method, described by DuBois et al. (1956), measures the soluble, readily available carbohydrate fraction in tissue.

Calculations. Shoot WUE was calculated by dividing the total shoot mass (leaf + stem) by the total amount of water applied to each plant after transplanting. Shoot P uptake efficiency was calculated by dividing the amount of $\mathrm{P}$ in the shoot (mg P in stem $+\mathrm{mg} \mathrm{P}$ in leaf) with the amount of $P$ supplied to each plant and expressed as a percent. Total $\mathrm{P}$ recovery efficiency was calculated by adding the amount of $\mathrm{P}$ measured in the root core samples with the shoot $\mathrm{P}$, dividing by the total $\mathrm{P}$ supplied, and expressed as a percent.

Statistical analysis. The experimental design was a split-plot design with three replicate blocks. Each block contained a single shade structure and an unshaded area on a single bench. Within each section, zinnia and vinca were grown at the six $\mathrm{P}$ treatment supplies. Each P supply was replicated for each species six times within each light treatment of each block. This resulted in a total of 216 plants of each species (six replicate plants $X$ six $P$ treatments $X$ three blocks $X$ two light levels). Each species was randomized separately.

Data were analyzed using linear regression in SigmaPlot (Version 11.2; Systat Software, Inc., San Jose, CA). Equations selected were "exponential decay":

$$
\mathrm{y}=\mathrm{y}_{0}+\mathrm{a} \cdot e^{-\mathrm{bx}}
$$

where $\mathrm{a}$ and $\mathrm{b}$ are constants unique to that response curve, $e$ is the natural log constant (2.714), $\mathrm{y}_{0}$ is a constant offset above zero on the $\mathrm{y}$-axis, and $\mathrm{x}$ and $\mathrm{y}$ are the independent and dependent variable, respectively; "exponential rise to maximum":

$$
\mathrm{y}=\mathrm{a}\left(1-e^{-\mathrm{bx}}\right)
$$

where a is a constant, $e$ is the natural log constant, and $\mathrm{x}$ and $\mathrm{y}$ are the independent and dependent variables, respectively; and "Gaussian peak":

$$
\mathrm{y}=\mathrm{y}_{0}+\mathrm{a} \cdot e^{\left[-0.5\left(\frac{\mathrm{x}-\mathrm{x}_{0}}{\mathrm{~b}}\right)^{2}\right]}
$$

where $\mathrm{a}$ and $\mathrm{b}$ are constants unique to that response curve, $e$ is the natural log constant, $\mathrm{y}_{0}$ is a constant offset above zero on the y-axis, $\mathrm{x}_{0}$ is a constant offset above zero on the $\mathrm{x}$-axis, and $x$ and $y$ are the independent and dependent variables, respectively. In each case 
after fitting the data to the equations described, an iterative process was used to identify the $\mathrm{P}$ concentration at which the response variable was maximized or minimized. Additionally, in the case of "exponential decay" or "exponential rise to maximum," the steady state of the response variable at infinite P supply was used as the highest or lowest possible value for that response variable. To obtain the minimum value of $P$ supply for maximum or minimum response, $90 \%$ of the highest or lowest value of the response variable was calculated and then used in an iterative process above to find the $\mathrm{P}$ supply that could elicit $90 \%$ of the maximum or minimum rates.

Data from the carbohydrate analysis were not analyzed with regression. Data were also analyzed with Statistix 9 (Analytical Software, Tallahassee, FL) using the "Split-plot Design" function. P supply and light (shaded or unshaded) were the main effects, and a two-way interaction was subjected to analysis of variance. Probability values $\leq 0.05$ were considered statistically significant. If interactions and/or main effects of interactions were determined to be significant, all possible pairwise comparisons were made with Tukey's honestly significant difference test $(\alpha=0.05)$. Comparisons between species were not made.

\section{Results}

Phosphorus and water supplied. Without shading, DLI was typically $\approx 15 \mathrm{~mol} \cdot \mathrm{m}^{-2} \cdot \mathrm{d}^{-1}$ but ranged from 12 to $20 \mathrm{~mol} \cdot \mathrm{m}^{-2} \cdot \mathrm{d}^{-1}$ during the study (data not shown). PAR within each block was approximately half under shaded compared with unshaded sections. Among blocks, there was small variation, typically less than $5 \%$, at any given moment in instantaneous light measurements.

For both species, the total amount of $\mathrm{P}$ supplied differed among treatments, but as a result of differences in total volume of fertigation supplied, a given $P$ treatment was not necessarily significantly different from another (Table 1). Shade treatments generally received less $P$ to each plant, but at the lowest three $\mathrm{P}$ supply treatments, there was no difference between sun- and shade-grown plants for total amount of $P$ supplied.

For unshaded vinca plants, the lowest two $\mathrm{P}$ supply rates required the least amount of water followed by the highest four P treatments (Table 2). All shade-grown vinca plants used the same amount of water regardless of $\mathrm{P}$ supply, with each $\mathrm{P}$ level lower than the same P level grown in full sun. For zinnia, the lowest P supply had the lowest water use, with the shade-grown plants significantly lower than the sun-grown plants. The four highest $P$ treatments had the highest water use with the sun-grown plants significantly greater than the shade-grown plants.

Vinca plant growth and phosphorus uptake. The lowest $P$ supply $(0.1 \mathrm{~mm})$ influenced the proportion of leaf mass; at the lowest $\mathrm{P}$ supply, shoots had an average of $74 \%$ leaf mass, whereas the highest $\mathrm{P}$ supply rates resulted in $68 \%$ leaf mass. There was statistically no difference between sun- and shadegrown fractions $(P=0.92)$ and the interaction was also not significant $(P=0.92)$. Because the partitioning between leaves and stems was not vastly different among the treatments, only the combined shoot mass (leaves + stem) is shown. Shoot mass increased as P supply increased to between $0.43 \mathrm{~mm}$ and $0.37 \mathrm{~mm}$ $\mathrm{P}$ (Fig. 1A) in sun- and shade-grown plants, respectively. Not surprisingly, full-sun plants were larger than shade plants at each P supply level. Shoot WUE was lowest at the lowest $\mathrm{P}$ supply (Fig. 1B). Shoot WUE increased substantially in other treatments, reaching its predicted maximum of $\approx 1.3 \mathrm{~g} \cdot \mathrm{L}^{-1}$ based on the regression analysis at a $\mathrm{P}$ supply of only $0.36 \mathrm{~mm} P$ supply. There was no further increase in shoot WUE with additional $\mathrm{P}$ supplied. There was no effect of light level on shoot WUE.

$\mathrm{P}$ supply influenced height in the same pattern as shoot mass; height increased up to $0.62 \mathrm{~mm}$ P supply, but no further significant increases were observed (Fig. 1C). The shade treatment had no influence on vinca height.
There was a slight delay in flowering of vinca as a result of low P supply (Fig. 1D). Plants receiving only $0.1 \mathrm{~mm} P$ flowered on average $2.6 \mathrm{~d}$ later than the average of all other $\mathrm{P}$ supply treatments. Shade also delayed flowering by an average of $1.8 \mathrm{~d}$. There was no influence on days to flower from the interaction between the shade treatment and P.

The total number of flowers (combining both open flowers and visible flower buds at harvest) was significantly influenced by $P$ supply but not by the shade treatment (Fig. 2A). Flower number increased to $0.5 \mathrm{~mm}$ $\mathrm{P}$ but did not significantly change beyond that $\mathrm{P}$ supply. Branch number, recorded because each branch in these species potentially ends in a flower or flower cluster, was also influenced by P supply but not the shade treatment (Fig. 2B). The most branches were obtained in a $\mathrm{P}$ supply of at least $0.2 \mathrm{~mm}$.

The supply of $\mathrm{P}$ significantly influenced the $\mathrm{P}$ concentration in the shoot, but the presence or absence of shade during growth had no effect (Fig. 3A). As expected, the lowest supply of $\mathrm{P}$ had the lowest $\mathrm{P}$ concentration and the concentration increased with P supply;

Table 2. Total nutrient solution supplied $(\mathrm{mL})$ in greenhouse production of vinca and zinnia plants in $10-\mathrm{cm}$ pots grown either in sun or under nearly $50 \%$ shade and fertilized with a complete nutrient solution with phosphorus $(\mathrm{P})$ concentrations varying from 0.1 to $4.0 \mathrm{~mm}$.

\begin{tabular}{lllcccrr}
\hline & \multicolumn{7}{c}{ P concn $(\mathrm{mm})$} \\
\cline { 3 - 7 } & & 0.1 & 0.2 & 0.5 & 1.0 & 2.0 & 4.0 \\
\hline Vinca & Sun & $1707 \mathrm{~b}^{\mathrm{z}}$ & $1750 \mathrm{~b}$ & $1917 \mathrm{a}$ & $1917 \mathrm{a}$ & $1917 \mathrm{a}$ & $1917 \mathrm{a}$ \\
& Shade & $1333 \mathrm{c}$ & $1300 \mathrm{c}$ & $1300 \mathrm{c}$ & $1300 \mathrm{c}$ & $1333 \mathrm{c}$ & $1300 \mathrm{c}$ \\
& Sun & $1692 \mathrm{c}$ & $2250 \mathrm{~b}$ & $3441 \mathrm{a}$ & $3541 \mathrm{a}$ & $3558 \mathrm{a}$ & $3558 \mathrm{a}$ \\
& Shade & $1317 \mathrm{~d}$ & $1567 \mathrm{c}$ & $2403 \mathrm{~b}$ & $2393 \mathrm{~b}$ & $2445 \mathrm{~b}$ & $2442 \mathrm{~b}$ \\
\hline
\end{tabular}

${ }^{\mathrm{z}}$ All data are means $(\mathrm{n}=18)$; values not sharing a common letter within a species are significantly different (Tukey's honestly significant difference test; $\alpha=0.05$ ).

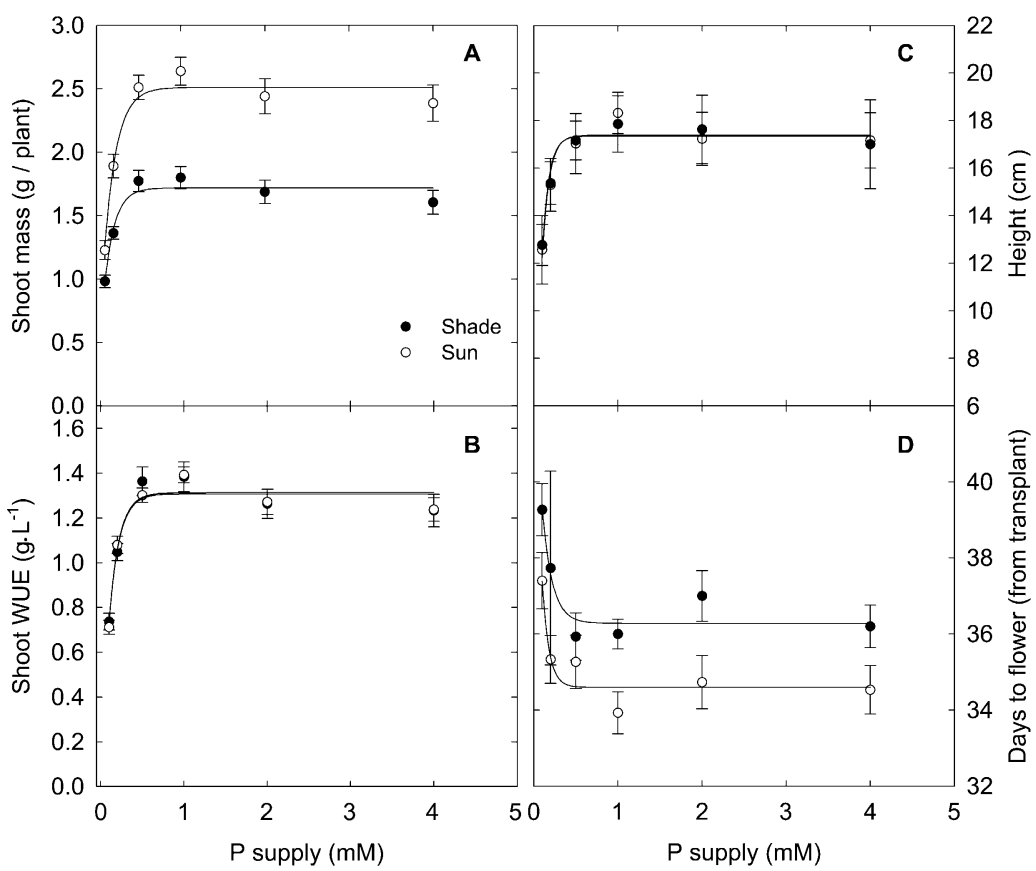

Fig. 1. Vinca mass of shoot (leaf and stem combined, A), shoot water use efficiency (shoot WUE, B), height at harvest $(\mathbf{C})$, and days to flower (D). Vinca was grown in a greenhouse in either full sun (open circles) or nearly $50 \%$ shade (closed circles) and irrigated with a complete nutrient solution that contained a phosphorus $(\mathrm{P})$ concentration of between 0.1 to $4.0 \mathrm{~mm}$. Values are means $(\mathrm{n}=18)$ with \pm 1 SEM. 
whereas the highest $\mathrm{P}$ supply was significantly different from the next two highest $P$ supply rates, the difference between those treatment means $\left(0.2 \mathrm{~g} \cdot \mathrm{kg}^{-1}\right)$ was small. In fact, all concentrations were deemed sufficient when supplied as little as $0.21 \mathrm{~mm} P$ (Mills and Jones, 1996). P content (concentration multiplied by shoot mass) had the same pattern as $\mathrm{P}$ concentration with total $\mathrm{P}$ amount ranging from $1.7 \mathrm{mg}$ per shoot in the shaded $0.1 \mathrm{~mm} P$ supply to $9.4 \mathrm{mg}$ per shoot in the highest $\mathrm{P}$ supply, shade-grown plants (Fig. 3B). Sun-grown plants had higher P content than shade-grown plants with $\mathrm{P}$ content plateauing at $\approx 14 \mathrm{mg}$ per shoot for sungrown plants and $\approx 9 \mathrm{mg}$ per shoot for shadegrown plants.

The range of $\mathrm{P}$ content, compared with the $\mathrm{P}$ supplied in milligrams over the 6 weeks of the experiment, resulted in significant differences in shoot $\mathrm{P}$ use efficiency ( $\mathrm{g}$ shoot biomass per mg $\mathrm{P}$ supplied). At the lowest $\mathrm{P}$ level, plants were able to grow $0.23 \mathrm{~g} \cdot \mathrm{mg}^{-1} \mathrm{P}$ supplied (Fig. 4A). The two highest $\mathrm{P}$ supply rates did not differ significantly from one another and ranged from 0.01 to $0.02 \mathrm{~g} \cdot \mathrm{mg}^{-1}$ $\mathrm{P}$ added. Shoot $\mathrm{P}$ recovery efficiency was predicted to be greatest at a $P$ supply rate of between $0.2 \mathrm{~mm}$ and $0.28 \mathrm{~mm} \mathrm{P}$, averaging $43.5 \%$ recovery across sun- and shade-grown treatments (Fig. 4B). The $0.1 \mathrm{~mm}$ and $0.5 \mathrm{~mm}$ $\mathrm{P}$ supply had similar recovery averaging $40.3 \%$ and $39.5 \%$, respectively, but were significantly different from the recovery at $0.2 \mathrm{~mm} P$ supply. At the highest $\mathrm{P}$ supply, only $5.8 \%$ of supplied $\mathrm{P}$ was transported to the shoots. When P recovered in the root zone was included in the mass balance, a similar, but not identical, pattern to the shoot uptake efficiency was observed (Fig. 4C). The lowest $\mathrm{P}$ supply had the highest recovery, exceeding $100 \%$, with an average of $171 \%$ recovery. Values higher than $100 \%$ indicate that some $P$ available in the peat substrate was acquired by the plants and that this small amount could account for a substantial proportion relative to total applied under P-deficient conditions. Unpublished data from this laboratory indicate that peat mixtures can contain over $200 \mathrm{mg} \cdot \mathrm{kg}^{-1}$ total $\mathrm{P}$ before leaching, and
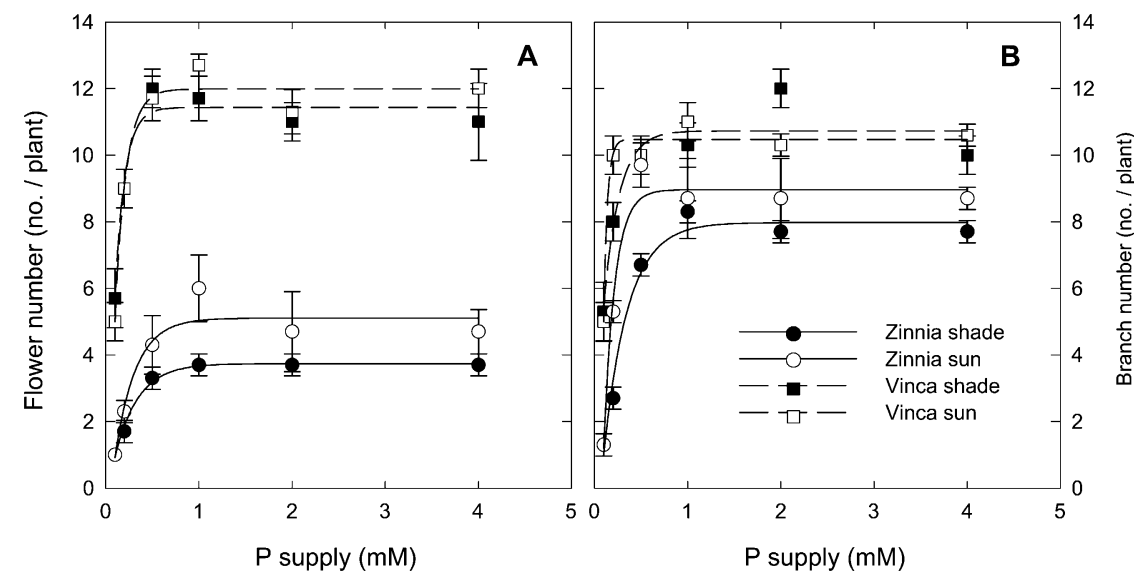

Fig. 2. Flower (A) and branch number (B) at harvest of vinca (square symbols; 6 weeks after transplanting) and zinnia (circle symbols; 9 weeks after transplanting). Number of flowers represented both open flowers and visible buds at harvest. Vinca and zinnia plants were grown in a greenhouse in $10-\mathrm{cm}$ pots either in sun (open symbols) or under nearly $50 \%$ shade (closed symbols) and fertilized with a complete nutrient solution with phosphorus $(\mathrm{P})$ concentrations varying from 0.1 to $4.0 \mathrm{~mm}$. Values are means $(\mathrm{n}=$ 18) with \pm 1 SEM.
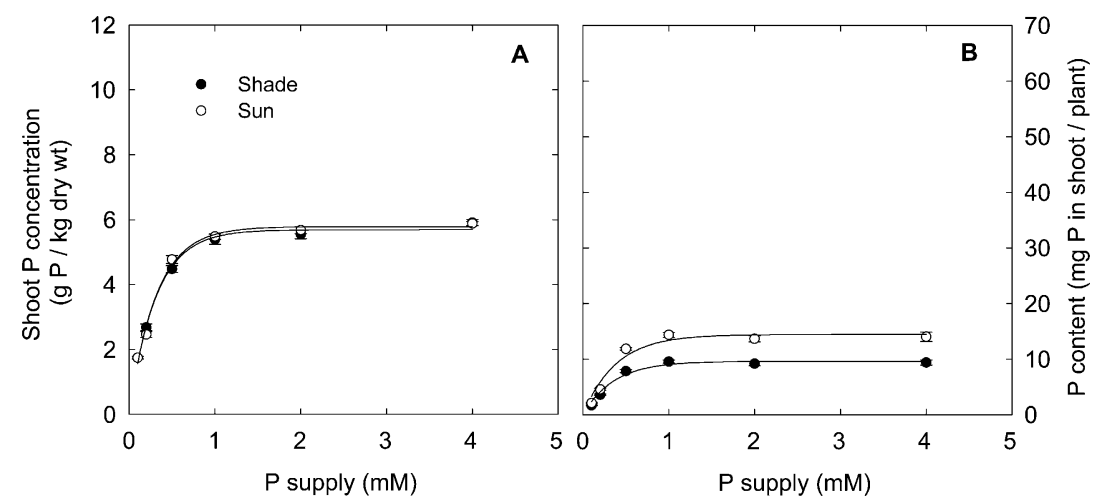

Fig. 3. Vinca phosphorus (P) concentration of the shoot (leaf and stem combined, A) and $\mathrm{P}$ content (concentration times plant size, B). Vinca was grown in a greenhouse in either full sun (open circles) or nearly $50 \%$ shade (closed circles) and irrigated with a complete nutrient solution that contained a $P$ concentration of between 0.1 to $4.0 \mathrm{~mm}$. Values are means $(n=18)$ with \pm 1 SEM.

because the containers used in this study were managed with minimal leaching, presumably some of this $\mathrm{P}$ could be available. If dry sphagnum peatmoss has a bulk density of $0.1 \mathrm{~g} \cdot \mathrm{cm}^{-3}$ (Handreck and Black, 2002) and each container held a volume of $400 \mathrm{~mL}$, the starting amount of total $\mathrm{P}$ from peat would be $\approx 8 \mathrm{mg}$ per container.

The three highest $\mathrm{P}$ supplies did not differ significantly from one another and had total recovery of between $72.7 \%$ and $86.9 \%$. Recovery efficiency of shade-grown plants was $\approx 10 \%$ more than in sun-grown plants.

Leaf carbohydrate concentration was significantly influenced by shade treatment and P supply, and the extent of influence from the shade treatment depended on P supply (Fig. 5). At low P supplies, the carbohydrate concentration of sun-grown plants was much higher than the shade-grown leaf tissue. At higher P supply rates ( $0.5 \mathrm{~mm}$ and above), carbohydrate concentrations were similar between the sun and shade treatments.

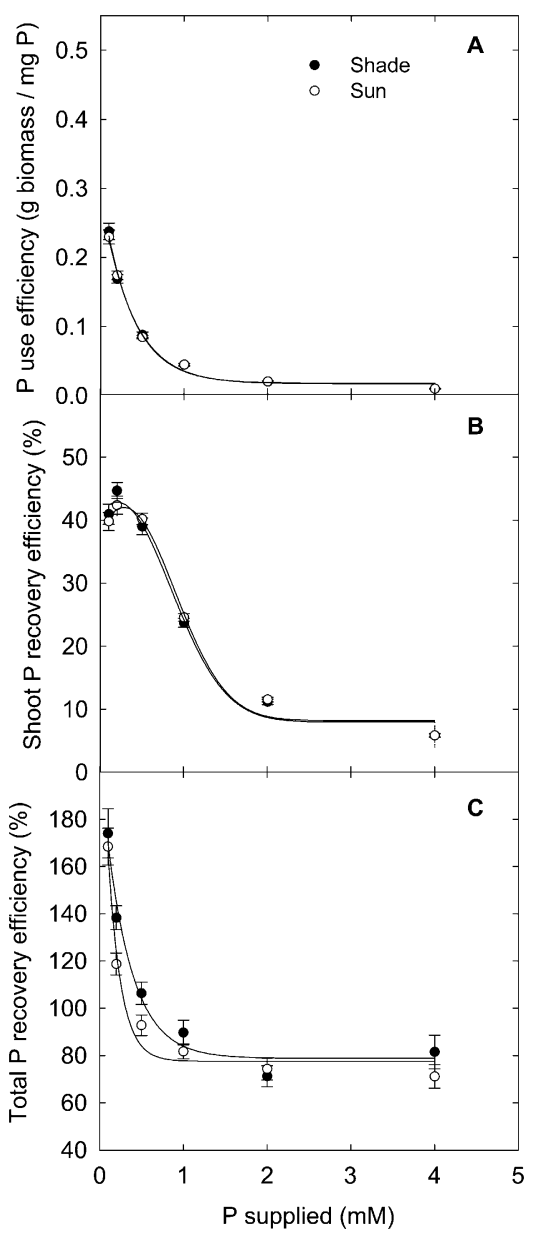

Fig. 4. Vinca shoot (leaf and stem combined) phosphorus (P) use efficiency (A), shoot recovery efficiency $(\mathbf{B}$, amount measured in shoot divided by the amount of $\mathrm{P}$ supplied), and total recovery efficiency $(\mathbf{C}$, combined shoot and root zone $\mathrm{P}$ divided by the amount of $\mathrm{P}$ supplied). Vinca was grown in a greenhouse in either full sun (open circles) or nearly $50 \%$ shade (closed circles) and irrigated with a complete nutrient solution that contained a $\mathrm{P}$ concentration of between 0.1 to $4.0 \mathrm{~mm}$. Values are means $(\mathrm{n}=18)$ with \pm 1 SEM. 
Zinnia plant growth and phosphorus uptake. Shade treatment had a significant effect on partitioning between leaves and stems with shade-grown plants having $37 \%$

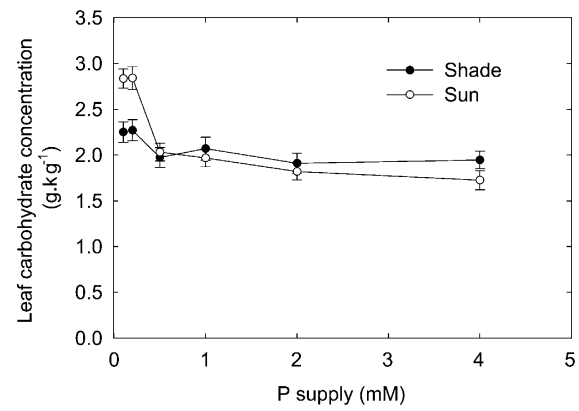

Fig. 5. Vinca leaf carbohydrate concentration. Vinca was grown in a greenhouse in either full sun (open circles) or nearly $50 \%$ shade (closed solution that contained a phosphorus (P) concentration of between 0.1 to $4.0 \mathrm{~mm}$. Values are means $(\mathrm{n}=18)$ with \pm 1 SEM. circles) and irrigated with a complete nutrient

leaf mass, whereas sun-grown plants had $40 \%$ of shoot mass allocated to leaves. The lowest $\mathrm{P}$ supply had a greater proportion of leaf mass in the shoot compared with the other treatments ( $46 \%$ to $39 \%$, respectively). Given the small biological difference in partitioning of tissue within the shoot, only total shoot mass is discussed hereafter. Zinnia shoot mass increased in a similar manner across $P$ supply as vinca (Fig. 6A).

Shoot WUE was again lowest in the lowest P supply (Fig. 6B). Shoot WUE increased from a low of $\approx 1 \mathrm{~g} \cdot \mathrm{L}^{-1}$ to nearly $3 \mathrm{~g} \cdot \mathrm{L}^{-1}$ at $\mathrm{P}$ supply rates of $0.5 \mathrm{~mm}$ or higher. Unlike vinca plants, shoot WUE did not decrease again at higher $P$ supply rates. WUE of shade-grown plants was significantly $(P=$ $0.0012)$ lower than those in full sun. There was no significant interaction effect between $P$ supply and shade on shoot WUE.

Zinnia height was influenced by both $\mathrm{P}$ supply and shade treatment (Fig. 6C). Shade plants were on average $7 \mathrm{~cm}$ taller than sungrown plants, whereas zinnia height at a $\mathrm{P}$

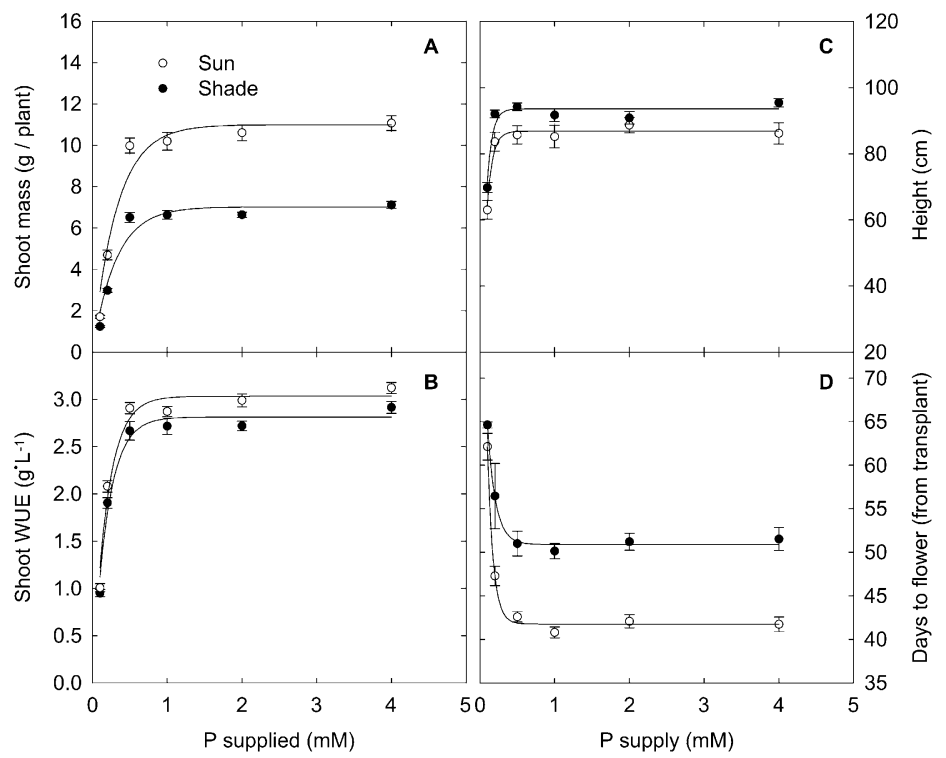

Fig. 6. Zinnia was grown in a greenhouse in either full sun (open circles) or nearly $50 \%$ shade (closed circles) and irrigated with a complete nutrient solution that contained a phosphorus $(\mathrm{P})$ concentration of between 0.1 to $4.0 \mathrm{~mm}$. Values are means $(\mathrm{n}=18)$ with \pm 1 SEM.
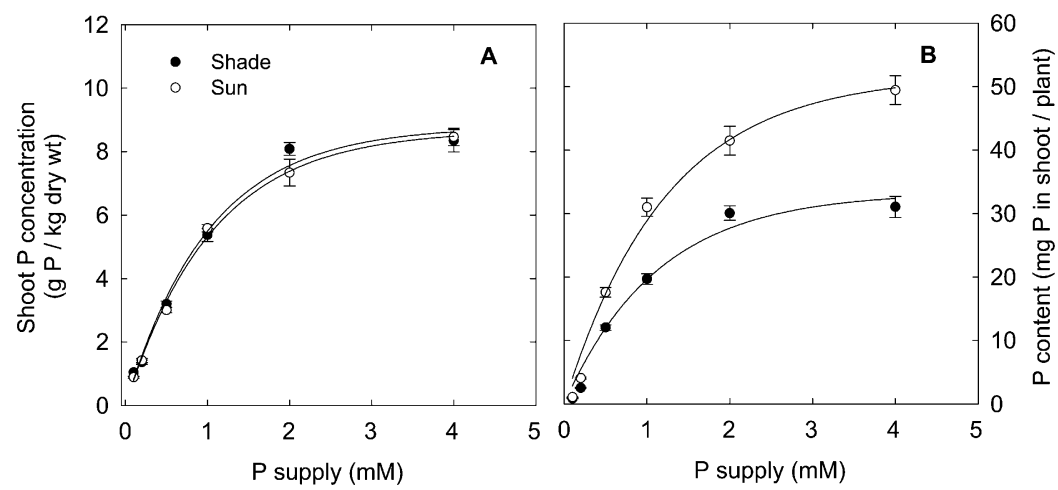

Fig. 7. Zinnia phosphorus (P) concentration of the shoot (leaf and stem combined, A) and $\mathrm{P}$ content (concentration times plant size, B). Zinnia was grown in a greenhouse in either full sun (open circles) or nearly $50 \%$ shade (closed circles) and irrigated with a complete nutrient solution that contained a $\mathrm{P}$ concentration of between 0.1 to $4.0 \mathrm{mM}$. Values are means $(\mathrm{n}=18)$ with \pm 1 SEM. supply of only $0.1 \mathrm{~mm} P$ was nearly $20 \mathrm{~cm}$ shorter than other $\mathrm{P}$ treatments. $\mathrm{P}$ supply also had a strong influence on days to flower (Fig. 6D). Many of the replicate plants in the lowest P supply never flowered or showed evidence of impending flowering, so for statistical purposes, those replicates were considered to have flowered $10 \mathrm{~d}$ after the termination of the experiment. Because this value was inserted and not measured, no specific comparisons are highlighted here between this treatment and any others. Flowering in plants receiving the second-lowest $\mathrm{P}$ supply, $0.2 \mathrm{~mm} \mathrm{P}$, was delayed by $5 \mathrm{~d}$ compared with all higher $P$ supplies, whereas shade generally delayed flowering by over 1 week.

Both P supply and shade influenced the amount of flowers with the peak flower numbers obtained in a $\mathrm{P}$ supply of $0.5 \mathrm{~mm}$ or higher (Fig. 2A). Plants grown in the shade had one to two fewer flowers than those grown in full sun when $P$ was above $0.5 \mathrm{~mm}$. Zinnia grown in full sun also had more branches than shade-grown plants at 0.2 and $0.5 \mathrm{~mm} P$ supply rates, which indicates greater potential flowering capacity (Fig. 2B). Once P supply reached $0.5 \mathrm{~mm}$, there were no further increases in branch number.

The supply of $\mathrm{P}$ influenced the concentration of $\mathrm{P}$ within the shoot, as expected (Fig. 7A). Shoot $P$ concentration significantly increased from 1.0 up to $8 \mathrm{~g} \cdot \mathrm{kg}^{-1}$ as P supply increased from $0.1 \mathrm{~mm}$ to $2.0 \mathrm{~mm}$ P. The two lowest supply rates had the lowest concentration with all other rates increasing the shoot tissue concentration up to $2 \mathrm{~mm} P$ supply. The sun or shade treatment had no influence on $\mathrm{P}$ concentration. Because of greater biomass accumulation in sun-grown plants (Fig. 6A), shoot $\mathrm{P}$ content (mg P in shoot tissue) was higher in sun-grown plants above $0.2 \mathrm{~mm}$ $P$. The influence of shade depended on the $\mathrm{P}$ supplied (Fig. 7B). At the lowest two P supplies ( 0.1 and $0.2 \mathrm{~mm} \mathrm{P}$ ), content was similar in both sun and shade treatments. $\mathrm{P}$ content was higher in sun-grown plants at a given $P$ supply than their shade-grown counterparts as a result of larger plants in the sun. At the highest $\mathrm{P}$ supply, content in shadegrown plants was over $18 \mathrm{mg}$ less than sungrown plants.

Phosphorus use efficiency was influenced by both shade and $\mathrm{P}$ supply, but there was no interaction (Fig. 8A). Plants were more efficient when grown in the sun, but as $\mathrm{P}$ supply increased, P use efficiency decreased. At the two lowest $\mathrm{P}$ supplies, $0.37 \mathrm{~g}$ of shoot tissue was produced per milligram $P$ supplied, but at the highest $\mathrm{P}$ supply, just $0.027 \mathrm{~g}$ was produced. The amount of $P$ recovered in the shoot relative to the total supplied was dependent only on P supply (Fig. 8B). The peak $\mathrm{P}$ recovery in the shoot was predicted to be achieved with a $\mathrm{P}$ supply of $0.76 \mathrm{~mm} \mathrm{P}$, whereas the highest $\mathrm{P}$ supply only provided a recovery of just over $11 \%$. When $\mathrm{P}$ recovered in the substrate was included, which accounts for both substrate and root tissue, the influence of both shade and P supply were also significant (Fig. 8C). In the shade-grown 


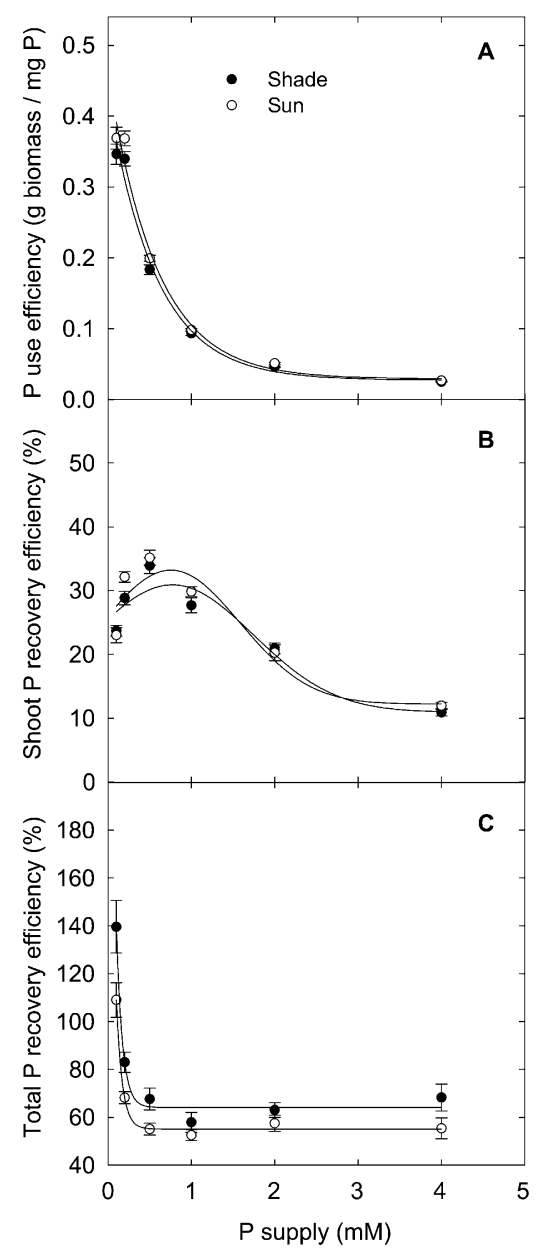

Fig. 8. Zinnia shoot (leaf and stem combined) phosphorus (P) use efficiency (A), shoot recovery efficiency $(\mathbf{B}$, amount measured in shoot divided by the amount of $P$ supplied), and total recovery efficiency $(\mathbf{C}$, combined shoot and root zone $\mathrm{P}$ divided by the amount of $\mathrm{P}$ supplied). Zinnia was grown in a greenhouse in either full sun (open circles) or nearly $50 \%$ shade (closed circles) and irrigated with a complete nutrient solution that contained a $\mathrm{P}$ concentration of between 0.1 to $4.0 \mathrm{~mm}$. Values are means $(\mathrm{n}=18)$ with \pm 1 SEM.

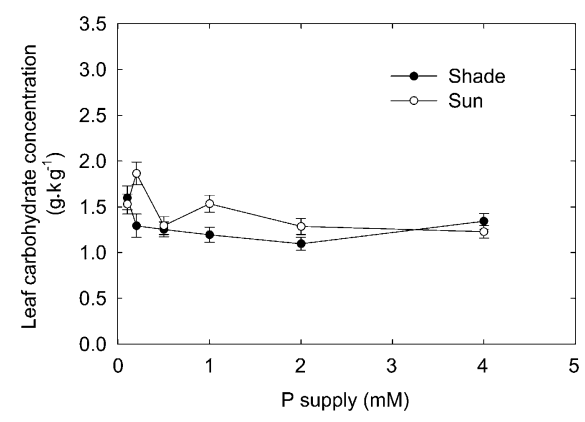

Fig. 9. Zinnia leaf carbohydrate concentration. Zinnia was grown in a greenhouse in either full sun (open circles) or nearly $50 \%$ shade (closed circles) and irrigated with a complete nutrient solution that contained a phosphorus $(\mathrm{P})$ concentration of between 0.1 to $4.0 \mathrm{~mm}$. Values are means $(\mathrm{n}=18)$ with \pm 1 SEM. plants, the highest percentage recovered was in the lowest P supply, at $140 \%$, whereas the highest $\mathrm{P}$ supply resulted in $68 \%$ recovery. Shade-grown plants had on average $79 \%$ recovery, which was statistically higher than sun-grown plants at $66 \%$ recovery. The interaction between light and P supply was not significant.

In a similar but not identical manner as vinca, the carbohydrate concentration in zinnia leaf tissue was significantly influenced by shade and $\mathrm{P}$ supply, and extent of influence from light depended on P supply (Fig. 9). Generally, the pattern of carbohydrate concentration was higher in sun conditions than shade regardless of $\mathrm{P}$ supply except at the lowest and highest $P$ supply rates. Generally, at the lowest $P$ supplies, the carbohydrate concentration was higher than at high $\mathrm{P}$ supply regardless of shade treatment.

\section{Discussion}

Manipulation of $\mathrm{P}$ supply in floriculture crop production is done primarily for control over plant appearance, chiefly height and flowering (Nelson et al., 2012). Height was only sensitive to $\mathrm{P}$ supply at the lowest $\mathrm{P}$ supply rates and quickly reached their maximum at only $0.5 \mathrm{~mm}$ P. At least in these crops, plant "stretch" was only stimulated when increasing from the lowest to the middle range of $\mathrm{P}$ supply. Flower number was also delayed only in the lowest P supply treatments, reaching its fastest flowering rates by $0.5 \mathrm{~mm}$ P. In fact, flowering was delayed uniformly by shade in zinnia $(\approx 10 \mathrm{~d})$ and delayed at most by $15 \mathrm{~d}$ under exceptionally low ( $0.1 \mathrm{~mm})$ rates of P supply compared with sufficient $\mathrm{P}$ (at or above $0.5 \mathrm{~mm}$ ). Flowering amounts also did not increase above $0.5 \mathrm{~mm}$ for either species. Whitcher et al. (2005) found "slightly more flowering at the higher P rates" in vinca with higher in their study meaning from 1 to $3 \mathrm{~mm}$ P. In our study, there was no benefit to flowering from supraoptimal $P$ supply (above $0.5 \mathrm{~mm}$ ). Adding $\mathrm{P}$ above these concentrations $(0.5 \mathrm{~mm} \mathrm{P})$ in an effort to enhance flowering is a practice that would only lead to lower P use efficiencies and likely greater $\mathrm{P}$ runoff.

A supply rate of $0.5 \mathrm{~mm} P$ is similar to supplying $\mathrm{P}$ in a " $20-10-20 "(20 \mathrm{~N}-4.4 \mathrm{P}-$ $16.6 \mathrm{~K}$ ) fertilizer mixture set at $72 \mathrm{mg} \cdot \mathrm{L}^{-1}$ nitrogen. Based on personal observations, fertilizers are supplied more often at a rate of between 100 and $200 \mathrm{mg} \cdot \mathrm{L}^{-1} \mathrm{~N}$, which indicates that $\mathrm{P}$ is oversupplied by $39 \%$ to $178 \%$, assuming this fertilizer mixture is used.

It appears that based on tissue nutrient concentration data as well as the lack of appearance of deficient or supraoptimal symptoms, shade did not influence the demand for $\mathrm{P}$ enough to change recommendations for P supply. Shade influenced overall plant growth, as expected, with larger plants resulting from unshaded conditions, but the tissue concentration was not significantly different at each $\mathrm{P}$ supply for each species. Although not tested in this study, it bodes well for other nutrient recommendations in drastically different light environments. That is, although the demand for nutrients was altered by vastly different light environments and resulting growth rates were influenced, final tissue concentration was unchanged given a set $\mathrm{P}$ concentration. This is similar to the findings of Lynch and González (1993) who found that Borojoa patinoi leaf P concentration was unchanged in response to light.

Total uptake of $\mathrm{P}$ changed in response to shade as a result of different plant sizes, indicating a regulation of $\mathrm{P}$ uptake as a result of demand rather than P supply. There was no luxurious $\mathrm{P}$ uptake at a given $\mathrm{P}$ supply rate. This was likely influenced by the P delivery method; plants were irrigated with fertilizer solution on an as-needed basis, and no leaching was done throughout the study. This meant that as plants grew and used water and nutrients, more was given to those treatments. As a result of faster plant growth in the sun treatments, water and nutrients were supplied more frequently. In that sense, P uptake was driven by demand, but $\mathrm{P}$ supply was also determined by applied $\mathrm{P}$ concentration and water demand.

A potential way to separate the supply and demand effects is by evaluating both WUE and carbohydrate concentration in the leaves. In the case of WUE, if growth is inhibited, the plant would continue using water for energy balance but consume less water per gram biomass as growth became non-limited. Gent (2008) found an increase in WUE in the initial 2 weeks after shading tomato, but it declined as fruit production decreased as a result of lower light. Both zinnia and vinca demonstrated growth restrictions and therefore poor water use rates at the lowest $\mathrm{P}$ supply. As $\mathrm{P}$ increased, the WUE also increased, maximizing at $\approx 1.3 \mathrm{~g} \cdot \mathrm{L}^{-1}$ in vinca and nearly $3.0 \mathrm{~g} \cdot \mathrm{L}^{-1}$ in zinnia. The calculated WUE for vinca was lower than other reported values from the literature, perhaps as a result of its determinant growth habit in general, or as a result of specific environmental conditions encountered in the present study, whereas the zinnia WUE was comparable to that of greenhouse-grown tomato (Gent, 2008) and field-grown carrot (Duacus carota) and snapbean (Phaseolus vulgaris), but less than fieldgrown bell pepper (Capsicum annuum) (De Pascal et al., 2011).

It has been observed that in conditions in which sink demand is low (for example, under low fertility), carbohydrate concentrations remain high compared with well-fertilized plants (Henry et al., 1992). In plants experiencing $\mathrm{P}$ deficiency, root sink activity is increased to assist soil exploration (Taylor et al., 2010). This increased root sink activity could result in decreased leaf carbohydrate concentration under $\mathrm{P}$ deficiency. In both crops, increased leaf carbohydrate concentration was observed at the two lowest $\mathrm{P}$ supply rates (0.1 and $0.2 \mathrm{~mm})$, suggesting that sink strength was still lower than potential photosynthetic supply. Based on WUE and carbohydrate concentrations, growth became non-limiting once $\mathrm{P}$ supply was increased to $0.5 \mathrm{~mm} P$. 
How effective plants are at taking up $\mathrm{P}$ and converting $\mathrm{P}$ into biomass was indicated by their $\mathrm{P}$ use efficiency and shoot recovery efficiency. It is desirable to have these values as high as possible, but the highest values are possible only under stress conditions. Low P supply stimulates high-affinity transporters (Raghothama, 1999), which are effective at scavenging any low amounts of $\mathrm{P}$, so plants can take advantage of low $\mathrm{P}$ supply in those conditions. Based on the WUE and carbohydrate analysis as well as height and rate of flowering data, plants of both species were experiencing stress at $\mathrm{P}$ supply rates lower than $0.5 \mathrm{~mm}$. Therefore, the peak $\mathrm{P}$ use efficiency and shoot recovery efficiency for vinca occurred in these lowest $P$ supply treatments; values for P use efficiency and shoot recovery efficiency were $0.08 \mathrm{~g}$ biomass $/ \mathrm{mg}$ $\mathrm{P}$ supply and just over $40 \%$, respectively. Optimal $\mathrm{P}$ use efficiency in unstressed zinnia plants was just under $0.2 \mathrm{~g}$ biomass $/ \mathrm{mg} \mathrm{P}$ with nearly $35 \%$ of the total $\mathrm{P}$ supplied recovered in the shoot. Based on the data presented here, the optimum $P$ supply rate is $0.5 \mathrm{~mm}$ for the highest growth, WUE, and $P$ use efficiencies for both zinnia and vinca.

These data demonstrate that recommendations for $\mathrm{P}$ supply can be made independent of light management in greenhouse production. Symptoms of deficiency or supraoptimal uptake of $\mathrm{P}$ were not exacerbated by changes in growth rates caused by differences in light supply, and the optimal rate of P supply, $0.5 \mathrm{~mm} \mathrm{P}$, was consistent between the two tested species. Below this supply rate, plant growth is limited, but above, $\mathrm{P}$ use efficiency decreases with no gains in other plant quality characteristics or flowering rates. Using standard fertilization practices, it is likely that $\mathrm{P}$ is excessively applied on plants with no apparent benefit to the plant and lost from the production system.

\section{Literature Cited}

Aberkani, K., X. Hao, D. de Halleux, M. Dorias, S. Vineberg, and A. Gosselin. 2010. Effects of shading using a retractable liquid foam technology on greenhouse and plant microclimates. HortTechnology 20:283-291.

Adams, P. 1980. Nutrient uptake by cucumbers from recirculating solutions. Acta Hort. 98:119-126.

Al-Arifi, I. 2006. Shading and air velocity influence on greenhouse microclimate. Acta Hort. 710: 219-224.
Aldrich, R.A. and J.W. Bartok, Jr. 1994. Greenhouse engineering. Natural Resource, Agriculture, and Engineering Service (NRAES)-33, Ithaca, NY.

Blanchard, M.G., E.S. Runkle, and P.R. Fisher. 2011a. Modeling plant morphology and development of petunia in response to temperature and photosynthetic daily light integral. Sci. Hort. 129:313-320.

Blanchard, M.G., E.S. Runkle, and J.M. Frantz. 2011b. Energy-efficient greenhouse production of petunia and Tagetes by manipulation of temperature and photosynthetic daily light integral. Acta Hort. 893:857-864.

Chapin, F.S., III, G.R. Shaver, A.E. Giblin, K.J. Nadelhoffer, and J.A. Laundre. 1995. Responses of arctic tundra to experimental and observed changes in climate. Ecology 76:694-711.

De Pascal, S., L.D. Costa, S. Vallone, G. Barbieri, and A. Maggio. 2011. Increasing water use efficiency in vegetable crop production: From plant to irrigation systems efficiency. HortTechnology 21:301-308

DuBois, M., K.A. Gilles, J.K. Hamilton, P.A. Rebers, and F. Smith. 1956. Colorimetric method for determination of sugars and related substances. Anal. Chem. 28:350-356.

Frantz, J.M. and B. Bugbee. 2005. Acclimation to shade: Photosynthesis, respiration, canopy quantum yield, and carbon use efficiency. J. Amer. Soc. Hort. Sci. 130:918-927.

Garland, K.F., S.E. Burnett, M.E. Day, and M.W. van Iersel. 2012. Influence of substrate water content and daily light integral on photosynthesis, water use efficiency, and morphology of Heuchera americana. J. Amer. Soc. Hort. Sci. 137:57-67.

Gent, M.P.N. 2007. Effect of degree and duration of shade on quality of greenhouse tomato. HortScience 42:514-520.

Gent, M.P.N. 2008. Density and duration of shade affect water and nutrient use in greenhouse tomato. J. Amer. Soc. Hort. Sci. 133: 619-627.

Gibson, J.L., D.S. Pitchay, A.L. Williams-Rhodes, B.E. Whipker, P.V. Nelson, and J.M. Dole. 2007. Nutrient deficiencies in bedding plants: A pictorial guide for identification and correction. Ball Publishing, Batavia, IL.

Handreck, K. and N. Black. 2002. Choosing materials for potting mixes. In: Growing media for ornamental plants and turf. UNSW Press, Sydney, Australia.

Henry, P.H., F.A. Blazinch, L.E. Hinesley, and R.D. Wright. 1992. Nitrogen nutrition of containerized eastern redcedar. I. Growth, mineral nutrient concentrations, and carbohydrate status. J. Amer. Soc. Hort. Sci. 117:563-567.

Jeong, K.Y., B. Whipker, I. McCall, C. Gunter, and J. Frantz. 2009. Characterization of nutrient disorders of gerbera hybrid 'Festival Light Eye Pink'. Acta Hort. 843:177-182.

Kim, J., M.W. van Iersel, and S.E. Burnett. 2011. Estimating daily water use of two petunia cultivars based on plant and environmental factors. HortScience 46:1287-1293.

Lynch, J. and A. González. 1993. Canopy nutrient allocation in relation to incident light in the tropical fruit tree Borojoa patinoi (Cuatr.). J. Amer. Soc. Hort. Sci. 118:777-785.

Mills, H.A. and J.B. Jones, Jr. 1996. Plant analysis handbook II: A practical sampling, preparation, analysis, and interpretation guide. MicroMacro Publishing, Athens, GA.

Nelson, P.V., C. Song, and J. Huang. 2002. What really causes stretch? Greenhouse Product News. January:24-28.

Nelson, P.V., C. Song, J. Huang, C.E. Niedziela, Jr., and W.H. Swallow. 2012. Relative effects of fertilizer nitrogen form and phosphate level on control of bedding plant seedlings growth. HortScience 47:249-253.

Nemali, K.S. and M.W. van Iersel. 2004. Light effects on wax begonia: Photosynthesis, growth respiration, maintenance respiration, and carbon use efficiency. J. Amer. Soc. Hort. Sci. 129:416-424.

Nobel, P.S. 1991. Physicochemical and environmental plant physiology. Academic Press, Inc., San Diego, CA.

Oh, W., I.H. Cheon, K.S. Kim, and E.S. Runkle. 2009. Photosynthetic daily light integral influences flowering time and crop characteristics of Cyclamen persicum. HortScience 44:341344.

Pramuk, L.A. and E.S. Runkle. 2005. Modeling growth and development of celosia and impatiens in response to temperature and photosynthetic daily light integral. J. Amer. Soc. Hort. Sci. 130:813-818

Raghothama, K.G. 1999. Phosphate acquisition Annu. Rev. Plant Physiol. Plant Mol. Biol. 50:665-693.

Stanton, K.M., S.S. Weeks, M.N. Dana, and M.V. Mickelbart. 2010. Light exposure and shade effects on growth, flowering, and leaf morphology of Spirea alba Du Roi and Spirea tomentosa L. HortScience 45:1912-1916.

Taiz, L. and E. Zeiger. 1991. Plant physiology. Bengamin/Cummings Publishing Co., Inc., Redwood City, CA.

Taylor, M.D., P.V. Nelson, J.M. Frantz, and T.W. Rufty. 2010. Phosphorus deficiency in Pelargonium: Effects on nitrate and ammonium uptake and acidity generation. J. Plant Nutr. 33:701712 .

Whitcher, C.L., M.W. Kent, and D.Wm. Reed. 2005. Phosphorus concentration affects new guinea impatiens and vinca in recirculating subirrigation. HortScience 40:2047-2051. 